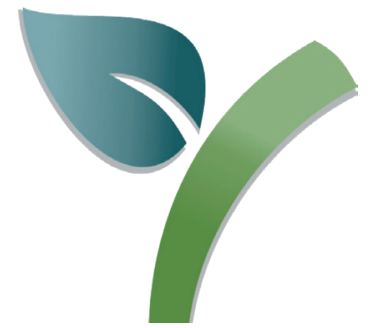

\title{
USO DE ESTERCO BOVINO E COBERTURA DE SOLO NO MANEJO DE NEMATOIDES NA CULTURA DA SOJA
}

\author{
Mauro Junior Natalino da Costa ${ }^{1}$
}

\section{RESUMO}

As doenças causadas por nematoides são consideradas importantes devido ao hábito polífago desses patógenos, estratégias de sobrevivência e aos prejuízos econômicos causados. No Brasil, as espécies que provocam os maiores danos na cultura da soja são: Meloidogyne javanica, M. incognita, Heterodera glycines, Pratylenchus brachyurus, Rotylenchulus reniformis e Aphelenchoides sp. Recentemente, surgiram relatos de incidência, em algumas regiões, de Tubixaba spp., Scutellonema brachyurus e Helicotylenchus dihystera. Dessa forma, é necessária a utilização de estratégias de manejo que auxiliem na redução dos níveis populacionais desses fitoparasitas. $\mathrm{O}$ uso de esterco bovino, associado a espécies vegetais para cobertura de solo, apresentase como uma alternativa para manejo de nematoides na cultura da soja, devido a um conjunto de propriedades nematostáticas e nematicidas, ao efeito benéfico às plantas e ao estímulo do desenvolvimento de inimigos naturais. São indicadas espécies de plantas que produzam resíduos que cubram melhor o solo, deixem mais palhada, distribuam seus sistemas radiculares pivotantes e/ou fasciculados, mantenham ou aumentem os teores de carbono, e incrementem a densidade/ riqueza macro e microbiológica. Esta revisão tem o objetivo de apresentar e discutir os principais efeitos do uso de matéria orgânica e alternativas de manejo e controle de nematoides na cultura da soja com o emprego de esterco bovino e cobertura de solo com diferentes espécies de plantas.

PALAVRAS-CHAVE: sistemas de produção, rotação de culturas, manejo da matéria orgânica do solo.

USE OF

BOVINE MANURE

AND SOIL

COVERAGE IN THE

MANAGEMENT OF

NEMATODES IN

SOYBEAN CULTURE

\section{SUMMARY}

The diseases caused by nematodes are considered important due to the polyphagous habit (wide range of host plants) of these pathogens, survival strategies and the economic losses. In Brazil, the species that cause the greatest damage in soybean crops are: Meloidogyne javanica, M. incognita, Heterodera glycines, Pratylenchus brachyurus, Rotylenchulus reniformis and Aphelenchoides sp. Recently there have been reports of incidence in some regions of Tubixaba spp., Scutellonema brachyurus and Helicotylenchus dihystera. Thus, it is necessary to use management strategies that reduce the population levels of these phytoparasites. The use of bovine manure, associated with soil coverage species, presents itself as an alternative for the management of nematodes in soybean crops, due to a set of nematostatic and nematicidal actions, which have a directly beneficial effect on plants and stimulate development of natural enemies. Thus, several species are used to produce residues that better cover the soil, leave more straw, distribute their pivoting and/or fasciculate

${ }^{1}$ UNIVAG Centro Universitário. Avenida Dom Orlando Chaves, Número 2.655, Bairro Cristo Rei, Várzea Grande (MT), CEP: 78.118900. mauro.costa@univag.edu.br 
root systems, maintain and/or increase carbon levels, and increase richness of macro and microbiological lives. This review aims to present and discuss the main effects of the use of organic matter and alternatives for the management and control of nematodes in soybean with the use of bovine manure and soil coverage with different plant species.

KEYWORDS: production systems, crop rotation, management of soil organic matter.

\section{INTRODUÇÃO}

A soja [Glycine max (L.) Merrill] é a oleaginosa mais produzida e comercializada no mundo. Seus derivados principais, o farelo (alto valor proteico) e o óleo, são usados tanto para a alimentação humana e animal, quanto para a produção de biocombustível e outros produtos químicos. Brasil, Estados Unidos da América e Argentina são responsáveis por mais de $80 \%$ da produção mundial. Apesar de, nos últimos anos, o Brasil ter registrado o maior crescimento na produção de soja entre esses três países, seu manejo vem enfrentando dificuldades devido a fatores bióticos e abióticos (LEMOS et al. 2017; USDA 2020). Nesse cenário, além de fatores abióticos como estiagens prolongadas, temperaturas elevadas e chuvas irregulares, observam-se ataques cada vez mais frequentes de pragas e patógenos (fungos, bactérias, vírus e nematoides), que impactam negativamente a produção, requerendo novas estratégias e tecnologias de manejo e controle (HIRAKURI 2014; EMBRAPA 2017).

Nematoides, de um modo geral, são considerados parasitas de difícil manejo e, por esse motivo, deve-se evitar sua introdução em locais ainda isentos desses organismos. Inicialmente, deve-se procurar identificar as espécies presentes na área de produção e, se possível, monitorar os diferentes pontos da propriedade, pois as populações podem diferir de um local para o outro. Amostras de solo e de raízes, em épocas chuvosas e com a presença de plantas em florescimento, geralmente permitem observações de picos populacionais de nematoides na cultura. Além disso, eles podem se hospedar em plantas daninhas, sobreviver em restos culturais e apresentar dormência prolongada (RITZINGER 2001; GOULART 2008; INOMOTO 2008).

Para o controle, recomenda-se o manejo integrado, constituído de um conjunto de ações para redução dos níveis populacionais desses fitoparasitas, com estratégias para cada espécie de nematoide que se apresenta na área de produção. Este manejo também deverá ser constituído de estratégias para estimular o desenvolvimento de raízes das plantas, em quantidade suficiente para garantir o desenvolvimento da parte aérea. Atualmente, as estratégias principais de manejo de fitonematoides são aquelas que diminuem custos, aumentam a produção e não agridem o ambiente. A utilização de matéria orgânica, a correção da fertilidade do solo, o controle biológico, o uso de variedades resistentes, a rotação de culturas, o uso de cultivos intercalares e a cobertura do solo são recomendados principalmente por reduzir a população dos nematoides e manter a biodiversidade nos diferentes agroecossistemas (TORRES et al. 2006; COSTA 2012; COSTA et al. 2014).

Nesta revisão, são apresentadas e discutidas alternativas de manejo e controle de nematoides na cultura da soja, com o emprego de esterco bovino e de espécies de cobertura de solo.

\section{NEMATOIDES NA CULTURA DA SOJA}

As doenças causadas por nematoides na cultura da soja são importantes devido à extensão das áreas atingidas e os prejuízos econômicos causados. No Brasil, as espécies que provocam os maiores danos na soja são: Meloidogyne javanica (Treub, 1885) Chitwood, 1949, Meloidogyne incognita (Kofoid \& White, 1919) Chitwood, 1949, Heterodera glycines (Ichinohe, 1952), Pratylenchus brachyurus (Godfrey, 1929) Filipjev \& Schuurmans Stekhoven, 1941, Rotylenchulus reniformis (Linford \& Oliveira, 1940) e Aphelenchoides sp. Fischer, 1894. Recentemente, o nematoide espiralado Helicotylenchus dihystera (Cobb, 1893) Sher, 1961, Scutellonema brachyurus (Steiner, 1938) Andrassy, 1958 e Tubixaba spp. Monteiro \& Lordello, 1980, passaram a fazer parte dos relatos de perdas em diferentes regiões do país tradicionais produtoras de grãos. O nematoide Aphelenchoides sp. é o único de parte aérea desta cultura e tem por hábito alimentar-se das inflorescências, 
flores e folhas da soja (FERRAZ 2001; MACEDA et al. 2009; FURLANETTO et al. 2010; MEYER et al. 2017).

As regiões com relatos recentes de perdas incluem: região centro-sul de Mato Grosso do Sul e grande parte do estado de Mato Grosso (nematoide-reniforme, sendo agravado a partir de 2010, em que 10 a 15\% das amostras passaram a apresentar incidência); Tocantins, Maranhão, Amapá, Pará e Norte de Mato Grosso (Soja-louca-II, sendo agravado a partir da safra 2005/06, mas com confirmação de agente causal somente em 2015); Paraná e Goiás ( $H$. dihystera, S. brachyurus e T. tuxaua, sendo relatadas perdas pontuais, mas preocupantes). Os estudos dessas três últimas espécies encontram-se em fase de compreensão da incidência e dos danos causados em lavouras de soja no Brasil, de maneira a trazer resultados mais confiáveis aos produtores (MACEDA et al. 2009; FURLANETTO et al. 2010; MEYER et al. 2017; SEIXAS et al. 2020).

Os danos causados pelos nematoides nas plantas hospedeiras são resultantes das ações espoliadora (alimentação e consumo de conteúdo de células vegetais), traumática ou mecânica (decorrentes do movimento interno nos tecidos) e tóxica (provocada por toxinas ou enzimas secretadas durante o parasitismo e que são prejudiciais à planta) (GOULART 2008). Na Tabela 1, são descritas as características morfológicas, bem como a sintomatologia dos oito principais fitonematoides da cultura da soja.

A importância econômica de cada espécie de nematoide varia de ano para ano e de região para região. Reduções de 30 a $50 \%$ no rendimento da soja foi relatada em 2007, no estado do Mato Grosso, por diversos produtores, com altas populações do nematoide-das-lesões ( $P$. brachyurus). Além disso, essa espécie apresenta elevada distribuição nas plantações de soja, sendo registrado em mais de $90 \%$ das amostras coletadas no mesmo estado. 0 nematoide-das-lesões foi beneficiado por mudanças no sistema de produção e a incorporação de áreas com solos de textura arenosa, onde a agressividade é maior. Relatos de danos e perdas econômicas têm sido preocupantes, além de provável ocorrência associada a outros patógenos (GOULART 2008; RIBEIRO et al. 2010).

Os primeiros registros de danos em soja pelo nematoide-das-galhas (Meloidogyne spp.), no Brasil, coincidem com a introdução da cultura no país. Sua polifagia e variabilidade fisiológica dificultam o estabelecimento de medidas de controle. Meloidogyne incognita e M. javanica são as espécies mais importantes para a cultura da soja no Brasil. M. javanica tem ocorrência generalizada, enquanto $M$. incognita predomina em áreas cultivadas anteriormente com café ou algodão. Nas lavouras de soja com problemas de nematoides-das-galhas, geralmente, observam-se reboleiras, onde as plantas apresentam sintomas de amarelecimento e subdesenvolvimento. As folhas das plantas afetadas podem apresentar manchas cloróticas ou necrose entre as nervuras, caracterizando a folha carijó. Pode não ocorrer redução no tamanho das plantas, mas, por ocasião do florescimento, nota-se intenso abortamento de vagens e amadurecimento prematuro das plantas. Em anos em que acontecem veranicos na fase de enchimento de grãos, os danos tendem a ser maiores. Há cultivares de soja resistentes ou moderadamente resistentes a $M$. incognita e/ou a $M$. javanica disponíveis no Brasil. Como os níveis de resistência dessas cultivares não são altos, em condições de elevados níveis populações do nematoide no solo, a utilização da cultivar resistente deverá ser precedida de rotação com uma cultura não hospedeira ou hospedeira desfavorável (ASMUS 2001; RIBEIRO et al. 2007).

O nematoide-dos-cistos ( $H$. glycines) foi relatado pela primeira vez, em 1915, no Japão, e em 1983 na Colômbia, em soja e feijão, respectivamente. No Brasil, os primeiros relatos surgiram a partir da safra 1991/1992, nos municípios de Nova Ponte (MG), Campo Verde (MT) e Chapadão do Sul (MS). Nas áreas onde é encontrado, ocorrem perdas na produção que variam de leves a $100 \%$, dependendo do nível de infestação, entretanto, não é de ocorrência generalizada e há muitas lavouras isentas do patógeno. Assim, a prevenção é importante. Hoje, o nematoide-dos-cistos apresenta a maior virulência e agressividade em áreas do estado de Mato Grosso, com ampla gama de raças identificadas $(1,2,3,4$, 4+, 5, 6, 9, 10, 14 e 14+). Existem, no Brasil, muitas cultivares comerciais de soja resistentes ao nematoide-dos-cistos, contudo, essa resistência é específica para determinadas raças. Atualmente, em muitas áreas de cultivo de soja, ocorre mistura populacional de raças, o que pode dificultar a efetividade dessa resistência. Outra dificuldade enfrentada no controle dos nematoides, é que, para facilitar o manejo da ferrugem asiática, os agricultores passaram 
Tabela 1. Características dos principais fitonematoides na cultura da soja e sintomatologia em plantas atacadas em raízes ou em parte aérea.

\begin{tabular}{|c|c|c|}
\hline Nematoide & Morfologia & Sintomatologia \\
\hline $\begin{array}{l}\text { Nematoide-das-galhas } \\
\text { (Meloidogyne spp.) }\end{array}$ & $\begin{array}{l}\text { - Fêmeas com comportamento endoparasita e } \\
\text { sedentário na raiz, globosas, de cor leitosa. A forma } \\
\text { infectiva é o juvenil de } 2 \text { o estádio (J2). }\end{array}$ & $\begin{array}{l}\text { - As raízes produzem galhas, devido } \\
\text { à expansão de células do cilindro } \\
\text { vascular. As folhas apresentam } \\
\text { amarelecimento e necroses entre as } \\
\text { nervuras. }\end{array}$ \\
\hline
\end{tabular}

\begin{tabular}{ll}
\hline Nematoide-dos-cistos & Fêmeas endoparasitas e sedentárias, contudo pode \\
(Heterodera glycines) & ser observada uma parte de seu corpo para fora das \\
& raízes. O cisto é a fêmea que após completar seu \\
& ciclo (morte), se desprende das raízes e fica no solo, \\
& contendo ovos no seu interior, os quais permanecem \\
& viáveis durante vários anos. A forma infectiva é o \\
& juvenil de 20 estádio (J2).
\end{tabular}

Nematoide-reniforme - Fêmeas semi-endoparasitas e sedentárias aumentam

(Rotylenchulus reniformis) de tamanho e adquirem o formato de um rim. A forma infectiva é o adulto fêmea.

- Reboleiras com plantas atrofiadas (nanismo) e cloróticas, podendo ser confundidas por deficiências nutricionais.

- Ocorre em reboleiras, onde nota-se amarelecimento das folhas, redução no porte das plantas e queda de produção.

- Indivíduos endoparasitas e migradores. O corpo é fusiforme. A forma infectiva corresponde a todos os indivíduos após a eclosão (2으, 3으 e 4을 estádios e adultos).
Nematoide-das-lesões (Pratylenchus spp.)
- Necrose e podridão no sistema radicular, favorecendo a entrada de fungos e bactérias. Na parte aérea observa-se a redução severa de porte ou morte.

\begin{tabular}{ll}
\hline Nematoide-da-haste- & - A relação parasitária de Aphelenchoides spp. com suas \\
verde ou Soja-louca-II & hospedeiras é descrita como ectoparasita. Estudos \\
(Aphelenchoides sp.) & indicam a possibilidade de que no patossistema \\
& soja-Aphelenchoides, possa ser endoparasitária, \\
& com a penetração nas raízes e no hipocótilo, e a \\
& sua movimentação ascendente até os sítios de \\
& alimentação ocorrendo internamente. \\
\hline
\end{tabular}

Nematoide Tubixaba tuxaua • Indivíduos ectoparasitas, ou seja, conseguem completar seu ciclo fora das raízes. Seu tamanho é exagerado, podendo atingir $10.000 \mu \mathrm{m}$.

- Plantas com enfezamento, nanismo e grãos chochos ou pequenos. Raízes apresentam-se lesionadas.

Nematoide Scutellonema
brachyurus

- São considerados como ectoparasitas de raízes, embora ocorram muitos relatos como endoparasitas nas camadas corticais mais profundas.

- Raízes apresentam lesões escurecidas nas raízes, semelhantes às causadas pelo nematoide-das-lesões.

- São considerados como ectoparasitas de raízes, embora ocorram muitos relatos como semi-

endoparasitas e até endoparasitas migradores.

- Lesões escurecidas nas raízes, semelhantes às causadas pelo nematoide-das-lesões.

Nematoide-espiralado
(Helicotylenchus dihystera)

- Folhas enrugadas e engrossadas, hastes deformadas e vagens com poucos grãos. Alteração no processo natural de maturação da planta.

Fonte: FERRAZ 2001; RITZINGER 2001; GOULART 2008; MACEDA et al. 2009; FURLANETTO et al. 2010 ; MEYER et al. 2017.

a optar por cultivares de soja precoces, que não correspondem à maioria das cultivares comerciais resistentes ao nematoide. A variabilidade genética do patógeno também tem contribuído para que a vida útil das cultivares resistentes seja reduzida (YUE et al. 2000; SEIXAS 2020).

Recentemente, o nematoide-reniforme $(R$. reniformis) e o nematoide-da-haste-verde ou Soja-louca-II (Aphelenchoides sp.) estão agravando o quadro epidemiológico de nematoides na cultura da soja, apresentando rápida expansão nas áreas de produção. O nematoide-reniforme é considerado um dos principais problemas da cultura do algodoei- ro, mas sua importância vem crescendo, nos últimos anos, em áreas cultivadas com soja e algodão em regiões do Cerrado brasileiro. Até recentemente, esse nematoide era considerado um patógeno secundário para a cultura da soja. Contudo, atualmente, é tido como espécie emergente nesta cultura, principalmente em lavouras do estado do Mato Grosso, onde sua ocorrência tem aumentado de forma consistente, e onde altas populações têm sido associadas a perdas em rendimento na cultura (TORRES et al. 2006; GALBIERI \& BELOT 2016).

Até o momento, não são evidentes os motivos da expansão da área infestada pelo nematoi- 
de-reniforme. Algumas hipóteses baseiam-se em sua habilidade de competir com outras espécies e de, em condições adversas, procurar camadas mais profundas do solo para sobreviver. A adaptação do nematoide-reniforme a diferentes texturas de solos permite a esse nematoide explorar ambientes que são inadequados a outros fitonematoides. Além dessas hipóteses, sua tolerância ao estresse hídrico, por um mecanismo de anidrobiose (juvenis enovelam-se sobre si e reduzem drasticamente o metabolismo), também tem sido considerada. $O$ manejo do nematoide-reniforme pode ser realizado, principalmente, por meio da rotação de culturas, uma vez que esse nematoide possui círculo de hospedeiros mais restrito, em relação a Meloidogyne spp. ou $P$. brachyurus, além do uso de cultivares resistentes. As cultivares de soja americanas Forrest e Custer são consideradas padrões de resistência ao nematoide-reniforme e estão sendo utilizadas como fontes de resistência no Brasil e, aparentemente, cultivares com resistência ao nematoide-dos-cistos também conferem resistência a $R$. reniformis (TORRES et al. 2006; GALBIERI \& BELOT 2016).

Duas áreas (sintomática e assintomática), localizadas na região da Serra da Petrovina, em Mato Grosso, foram avaliadas quanto às perdas na produção de algodão afetadas por $R$. reniformis, $P$. brachyurus e $M$. incognita, com reduções no rendimento de $35 \%$ na cultivar FMT 701 , e de $23,1 \%$ na cultivar IMACD 6001 LL (SILVA et al. 2014).

Recentemente, o nematoide espiralado $H$. dihystera, S. brachyurus e Tubixaba spp. passaram a fazer parte dos relatos de perdas em diferentes regiões do país. Tanto $H$. dihystera como $S$. brachyurus são consideradas espécies ectoparasitas, ou seja, que não teriam a capacidade de penetrar nas raízes das plantas e, portanto, os danos causados ao sistema radicular seriam menores. Porém, trabalhos recentes têm indicado que ambos conseguem penetrar no sistema radicular da soja, ao contrário do que se esperava em função do hábito de parasitismo desses nematoides, e, além disso, causar lesões semelhantes àquelas provocadas por $P$. brachyurus, o nematoide-das-lesões. O amplo círculo de hospedeiras de Tubixaba tuxaua é um indicativo de que este nematoide apresenta um hábito alimentar pouco especializado, com um odontoestilete curto e largo, característico de nematoides onívoros (FURLANETTO et al. 2008; MACEDA et al. 2009).

\section{EFEITOS DA MATÉRIA ORGÂNICA E ESTERCO BOVINO NO CONTROLE DE NEMATOIDES NA CULTURA DA SOJA}

A matéria orgânica do solo é originalmente produzida por organismos vivos, que disponibilizam gradualmente os nutrientes às plantas, minimizando as perdas por lixiviação. Esta matéria orgânica não aumenta a acidez do solo, já que tem seu pH próximo à neutralidade ou superior a 7,0. Se bem decomposta e humificada, favorece ainda o equilíbrio microbiológico no solo, colaborando intensamente no controle de algumas pragas e doenças, como aquelas causadas pelos nematoides (DIXIT 2005). Assim, o contínuo aporte de material orgânico é fonte de energia para a atividade microbiana, que atua como agente de estabilização dos solos. Além disso, a matéria orgânica, em razão de sua estrutura complexa e de longas cadeias de carbono, agrega partículas minerais, com efeito direto na formação e na estabilização dos agregados, fundamental no processo de manejo do solo onde se encontram os nematoides (DUFRANC et al. 2004; BRAIDA et al. 2010).

Grande parte das espécies vegetais cultivadas sobre solos arenosos, e com teores baixos de matéria orgânica, apresenta maior suscetibilidade aos nematoides (nematoides são mais agressivos nessas condições). Assim, qualquer tipo de adição de produtos, tais como estercos e palhadas, pode apresentar efeito de supressão das populações e melhoria do sistema radicular. Em solos nos quais não há materiais que podem ser decompostos, a adição de matéria orgânica favorece o início dos processos de multiplicação de bactérias, fungos e actinomicetes, que logo a irão decompor. Também há aumento da capacidade de retenção de água no solo e melhora da atividade de organismos que são antagonistas aos nematoides. São atribuídos à matéria orgânica diversos efeitos sobre as populações de nematoides e suas plantas hospedeiras. Há relatos de que o principal efeito ocorre na multiplicação de populações dos inimigos naturais, como fungos e bactérias antagonistas, nematoides predadores e protozoários. Há, ainda, a liberação de compostos tóxicos com ação nematicida, como o ácido butírico e ácidos graxos voláteis (TORRES et al. 2006; COSTA 2012; COSTA et al. 2014).

De acordo com Coutinho et al. (2018), as comunidades de nematoides nos solos são um reflexo da composição da vegetação e podem ser utilizadas 
como indicadores de distúrbios ambientais, com redução das populações desses organismos em áreas com menor complexidade vegetal. Isto demonstra como a dinâmica de populações de nematoides pode ser alterada de forma a tornar o solo mais supressivo. Zane et al. (2019) observaram um aumento significativo de bactérias benéficas, decompositoras, em solo adicionado com esterco de suínos, diferentemente no solo que teve apenas a utilização de fertilizantes químicos (nitrogênio e potássio), sendo que a maior quantidade foi observada 45 dias após a semeadura. Assim, a gestão da matéria orgânica do solo surge como uma alternativa promissora de manejo, tendo-se em vista inúmeros benefícios na redução populacional de nematoides, bem como no desenvolvimento das plantas (SOUZA et al. 2006; ALMEIDA 2008).

Desde que se observou uma significativa redução de populações do nematoide-das-galhas durante a decomposição da matéria orgânica, vários trabalhos foram realizados com o mesmo propósito. Observaram-se modificações nas condições físicas e químicas do solo que podem alterar a relação hospedeiro-parasita. Neste sentido, a matéria orgânica altera a fisiologia do hospedeiro, o que resulta em maior resistência ao desenvolvimento populacional dos nematoides nas raízes. A matéria orgânica pode acelerar o desenvolvimento radicular, o que permite maior absorção de nutrientes, diminuindo os efeitos dos danos causados pelos patógenos radiculares (NAZARENO 2009).
A matéria orgânica nos solos consiste de uma mistura de produtos em diferentes estágios de decomposição, resultantes da degradação biológica de resíduos vegetais e animais e da atividade microbiana (Figura 1). Ela tem sido subdividida em húmus e substâncias não húmicas. O termo "substâncias húmicas" refere-se à categoria de materiais de ocorrência natural, que podem ser encontrados em todos os sistemas terrestres e aquáticos, constituindo uma das mais abundantes formas da matéria orgânica na superfície da terra (ROSA et al. 2001).

Os ácidos húmicos se referem à fração que não é solúvel em água sob condições ácidas, podendo tornar-se solúvel (ou extraível) em condições de $\mathrm{pH}$ mais altos, o que reforça a importância da correção dos solos no manejo da fertilidade, e no manejo integrado de nematoides. Por outro lado, os ácidos fúlvicos são solúveis em meio aquoso em qualquer condição de $\mathrm{pH}$. As análises da composição elementar de ácidos húmicos extraídos de vários solos mostram valores de carbono que variam de 49 a $62 \%$; hidrogênio de 3 a 6\% e nitrogênio de 0,45 a 5,0\% (MACCARTHY 2001).

Os ácidos húmicos e fúlvicos são os compostos mais importantes das frações húmicas, com relação à reatividade e ocorrência nos ecossistemas. A proporção entre as substâncias húmicas e o carbono total em resíduos orgânicos é denominada grau de humificação, a qual é dependente do nível de decomposição em que essas substâncias se encontram. De acordo com Torres \& Pereira (2008) o

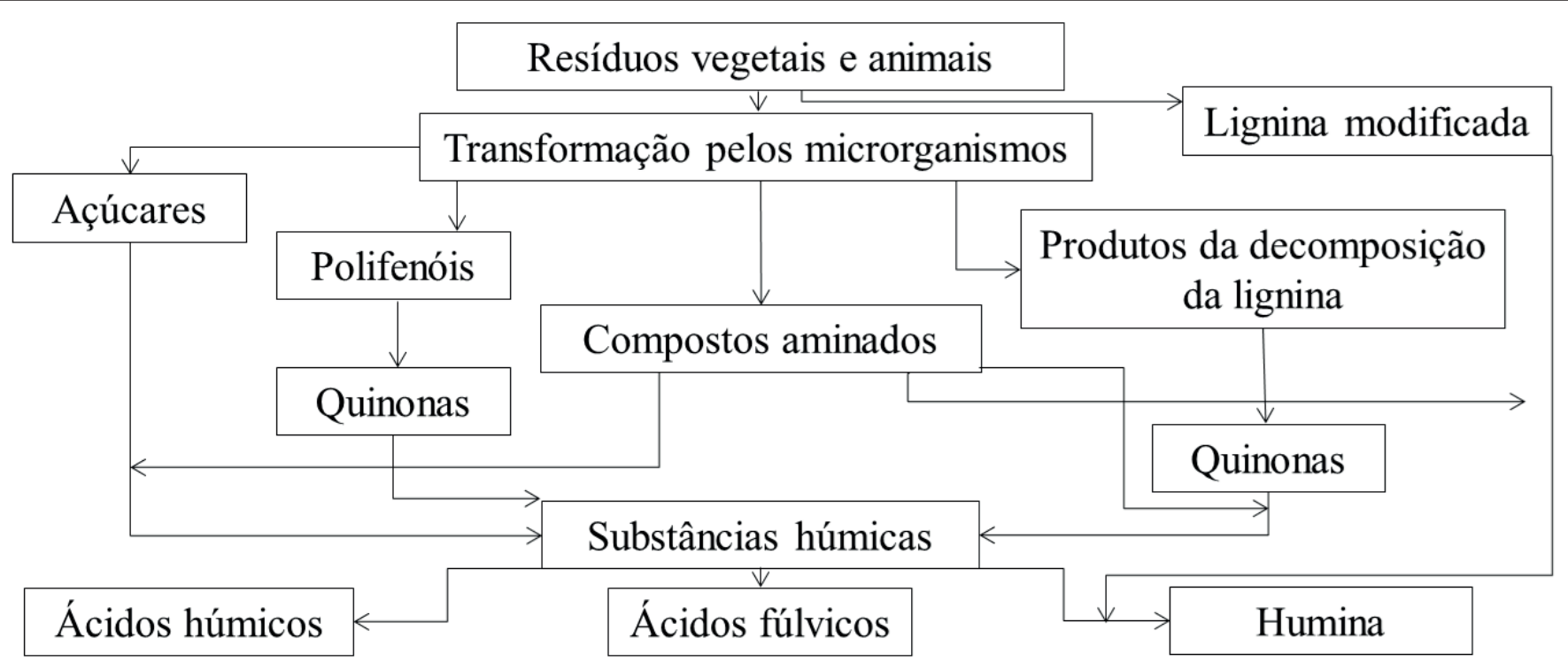

Figura 1. Diferentes etapas do processo de decomposição da matéria orgânica e formação das substâncias húmicas para o manejo de nematoides (ROSA et al. 2001). 
esterco bovino se encontra dentro da faixa ótima na relação C:N compreendida entre 14:1 e 20:1, com condições de atingir este processo em campo quando direcionado para o manejo de nematoides.

Quanto às interferências das substâncias húmicas no metabolismo das plantas, devido à sua capacidade de troca catiônica, possuem a propriedade de complexar e, com isso, disponibilizar cátions às plantas, principalmente micronutrientes. Estas interferências não só estão relacionadas com os nutrientes que estas substâncias fornecem para as plantas, mas também devido ao estímulo direto no desenvolvimento e no metabolismo. Efeitos positivos foram demonstrados na germinação de sementes, no crescimento inicial das raízes, na biomassa da planta e no auxílio na defesa da planta contra estresses. Umas das hipóteses sobre o mecanismo com que os ácidos húmicos e fúlvicos modificam a arquitetura da raiz envolve a síntese de auxinas (hormônio que favorece, dentre outras funções, o crescimento lateral de raízes). Estas interferências no metabolismo são fundamentais para acelerar o desenvolvimento em condições de ataque de nematoides (NARDI et al. 2005).

O estímulo aos receptores de auxinas foi confirmado em um estudo de Trevisan et al. (2010). Os autores mostraram que no uso de substâncias húmicas em plantas de Arabidopsis thaliana houve ativação de raízes laterais e expressão do gene IAA 19. Os membros das famílias AUXIN RESPONSE FACTOR (ARF) e AUX/IAA são genes relativamente bem conhecidos em Arabidopsis sp. devido às suas funções na via de sinalização de auxina, em processos de crescimento e desenvolvimento. São estas as razões da importância para as plantas, tendo-se em vista que levam à convivência com os nematoides. Sabe-se que os efeitos benéficos sobre a fisiologia vegetal levam à produção sustentável, mesmo com a presença de níveis médios populacionais destes parasitas no solo. Substâncias húmicas são também reconhecidas como componentes fundamentais da fertilidade, já que elas controlam as propriedades biológicas e químicas da rizosfera (GUILFOYLE \& HAGE 2007).

Em tomateiro, também foi observada a ativação da transcrição de promotores responsivos à síntese de auxinas. Esta síntese é importante para o desenvolvimento da raiz e estimula a formação de raízes laterais, aumentando a absorção de água e nutrientes. Em milho, foi demonstrado que o estímulo para a modificação da arquitetura radicular especialmenmte o surgimento de raízes laterais, envolve a produção de óxido nítrico, após a aplicação de ácidos húmicos. $O$ óxido nítrico estimula a atividade de síntese de auxinas, acidificando o apoplasto e contribuindo para o afrouxamento das paredes celulares, permitindo o crescimento da raiz. Como as raízes laterais são mais finas, têm maior atividade e absorvem maior quantidade de nutrientes e água do que as raízes principais. Com a maior produção de raízes, mesmo com o ataque de nematoides, há volume radicular suficiente para atender à demanda vegetal. Quando na presença de substâncias húmicas, aumentam em quantidade e tamanho, já que são estimuladas pelos ácidos húmicos e fúlvicos (ZANDONADI et al. 2010).

Substâncias húmicas estimulam a expressão diferencial de genes vegetais (dependentes de um estímulo). Em teoria, a ativação destes genes pode tornar a planta menos sensível aos estresses (nematoides) pelo aumento da capacidade de resposta. Assim, a planta sob o estresse em questão, gera, em contrapartida, uma resposta. Isto tem impacto positivo na agricultura, pois resulta em plantas mais tolerantes. Assim, é possível contribuir para a expressão de proteínas e síntese de determinados constituintes proteicos (RYAN 2000; TREVISAN et al. 2010). Entre as proteínas de defesa a patógenos, incluindo os nematoides, destacam-se as lectinas, inibidores de proteases serínicas e cisteínicas, polifenoloxidases, peroxidases, fenilalanina-amônia-liase e as proteínas relacionadas à patogênese (PRPs), sendo estas mais bem descritas quanto às suas propriedades de defesa vegetal. Sabe-se que estas proteínas de defesa são ativadas através dos ácidos húmicos e ácidos fúlvicos num processo conhecido como síntese de componentes de resistência dinâmica (Figura 2) (SIQUEIRA-JÚNIOR et al. 2002; DE WIT 2007; CHEN 2008; PINTO et al. 2011).

$\mathrm{Na}$ síntese de componentes da resistência, sinais bioquímicos são desencadeados na célula vegetal, ativando genes de resistência horizontal, também denominada de resistência quantitativa, e permitindo a expressão de mecanismos de defesa contra os nematoides (SIQUEIRA-JÚNIOR et al. 2002; DE WIT 2007; CHEN 2008; PINTO et al. 2011).

Os ácidos húmicos e fúlvicos, além de resultarem em crescimento do sistema radicular, tam- 
bém incrementam a biomassa da parte aérea. Isto se deve a uma ativação das ATPases (enzimas catalisadoras) presentes na membrana celular, que levam a uma maior troca de íons e maior absorção de nutrientes, como nitratos, os quais favorecem o crescimento vegetativo. Estas evidências também foram encontradas em estudos com milho e pepino (CANELLAS et al. 2001; QUAGGIOTTI et al. 2004; ZANDONADI et al. 2007; AGUIRRE et al. 2009; MORA et al. 2010).

Bowden et al. (2010) evidenciaram efeitos positivos para a cultura da soja, quando manejada em solos orgânicos constituídos de substâncias húmicas. Houve aumento no rendimento (9-21\%), teor de proteínas (4-9\%) e peso dos grãos (5-14\%), devido ao melhor uso da água e dos nutrientes disponíveis no solo. Porém, para a cultura do milho, este efeito não foi o mesmo. A resposta positiva no rendimento foi relacionada mais com o acúmulo de nitrogênio nas folhas, do que com o carbono do solo humificado. Ressalta-se, porém, que a compreensão de fatores bióticos estressores, como nematoides, deve ser um critério de estudo correlacionado à avaliação dessas substâncias (BOWDEN et al. 2010). Resultado semelhante foi obtido por Verlinden et al. (2009) quando cultivaram milho com substâncias húmicas (mistura líquida de $12 \%$ de ácido húmico e $3 \%$ de ácido fúlvico). Foi observado um pequeno aumento no rendimento, quando o milho foi cultivado em solo argiloso, e não houve efeito das substâncias húmicas, quando cultivado em solo arenoso. Isso pode ter ocorrido pela menor integração com os complexos de areia, já que os ácidos húmicos precipitam em condições de solo arenoso, pois são formadas forças de repulsão pela interação areia e ácidos húmicos.

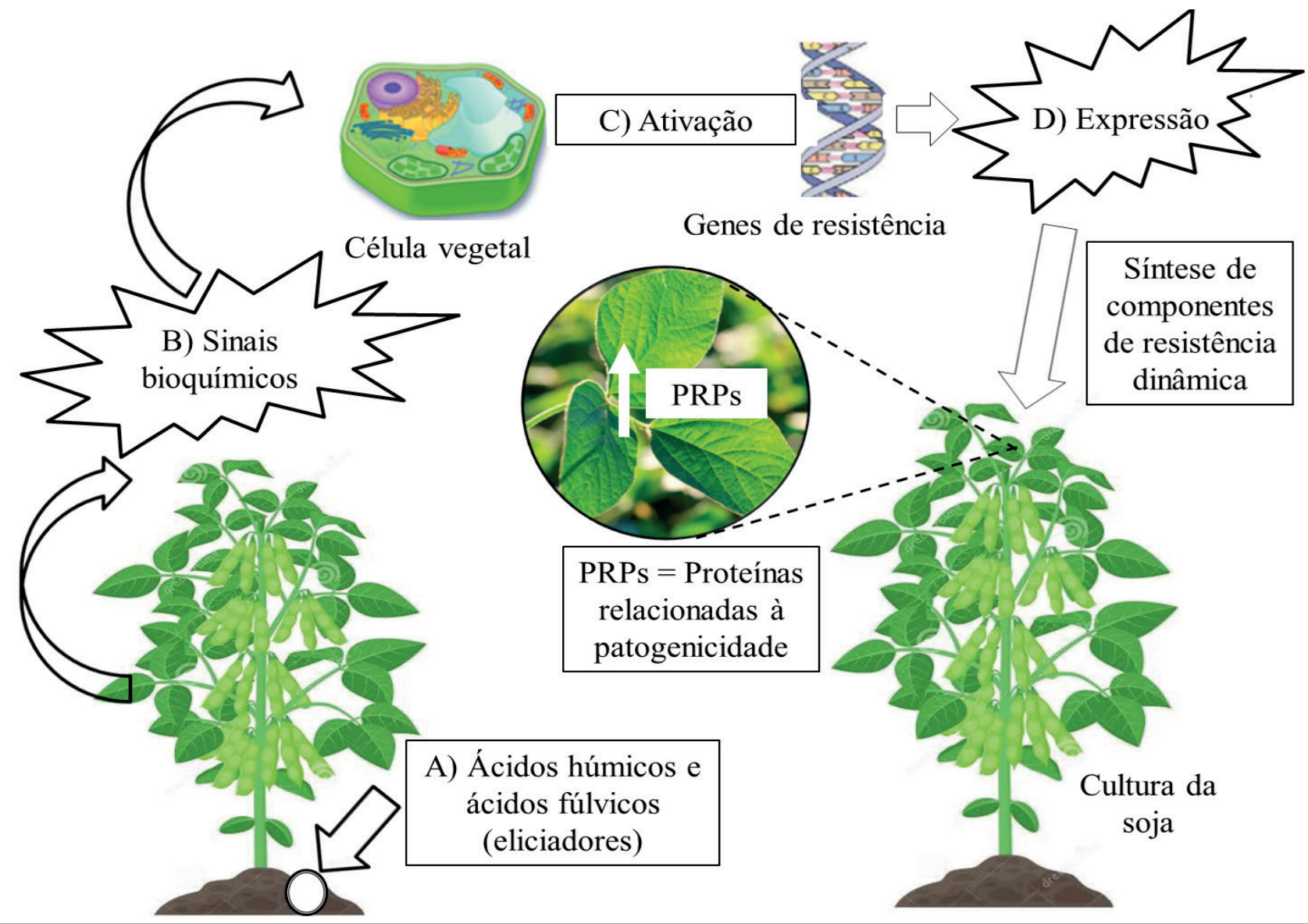

Figura 2. A. Substâncias húmicas produzidas na decomposição do esterco são absorvidas na solução do solo pelas raízes; B. Sinais bioquímicos desencadeiam respostas no interior das células vegetais; C. A ativação de genes que dependem de estímulos é iniciada, podendo tornar a planta menos sensível ao ataque dos nematoides, gerando, em contrapartida, uma resposta resistente; D. Entre as proteínas de defesa contra patógenos presentes em plantas, destacam-se as lectinas, inibidores de proteases serínicas e cisteínicas, polifenoloxidases, peroxidases, fenilalanina-amônia-liase e as proteínas relacionadas à patogênese (PRPs), sendo estas últimas melhor descritas quanto às suas propriedades de defesa vegetal. Adaptado de STANGARLIN et al. (2011). 
Entre os compostos sintetizados pelas plantas, os fenóis são conhecidos por atuarem na resistência ao nematoide-das-galhas. A adição de esterco bovino pode elevar o nível de fenóis nas raízes da planta hospedeira, deformando as células gigantes e engrossando as paredes celulares, o que torna a planta mais resistente. Assim, Alves et al. (2007) utilizaram substrato formulado na proporção de 1:1 de solo e areia, adicionaram diferentes quantidades de esterco bovino e observaram que ocorreu um aumento da concentração de fenóis nas raízes, prejudicando o desenvolvimento de Meloidogyne spp. Os autores, inclusive, observaram fêmeas de tamanho menor, de acordo com o aumento da porcentagem de esterco no substrato de plantio do tomate. Os estudos mostraram sítios de alimentação menores, em menor quantidade e com deformações, com paredes mais espessas e com menor número de núcleos, se comparados àqueles de plantas cultivadas nos substratos com baixa taxa de matéria orgânica (esterco bovino). Plantas resistentes a Meloidogyne spp. podem apresentar células gigantes com vacúolos menores, menor desenvolvimento, escurecimento do citoplasma e depósito de calose em células adjacentes àquelas invadidas (FONSECA et al. 2003; RODRIGUES et al. 2003).

A atividade nematicida da matéria orgânica no solo pode ser atribuída à mineralização química liberando amônia, aumentando os níveis de nitrogênio e dióxido de carbono, reduzindo o nível de oxigênio; pela liberação de compostos tóxicos, ou pelo aumento no número de fungos e bactérias antagonistas a fitonematoides. Essas substâncias possuem efeito nematicida ou nematostático, ou ainda podem interferir na eclosão de juvenis (SUZUKI \& ALVES 2006).

Em trabalho realizado por Kimpinsk et al. (2003) na cultura da batata, utilizando-se esterco bovino, em solos infestados com $M$. javanica e $M$. incognita, observou-se um aumento do rendimento, em média de $27 \%$, após um período de sete anos de trabalho. Todavia, a utilização dos compostos aumentou a população dos parasitas com o passar do tempo. Esse resultado comprova que a utilização de materiais orgânicos na forma de esterco pode ter resultados discrepantes, dependendo do momento da avaliação. Assim, com o aumento de raízes, dependendo da época que for realizada a avaliação, observam-se aumentos populacionais. O aumento do rendimento pode estar relacionado ao melhor desenvolvimento radicular estimulado pela matéria orgânica e ao controle do nematoide na fase inicial de desenvolvimento da lavoura (KIMPINSK et al. 2003).

Santos et al. (2017) avaliaram a altura (porte) e o vigor da cultura da soja inoculada em casa-de-vegetação com $P$. brachyurus, quando tratada com diferentes tipos de esterco e palhadas de cobertura. Os melhores resultados foram aqueles em que se utilizaram 2 ou 4 toneladas/ha de cama de frango + palhada de milho + palhada de crotalária. Estes efeitos foram observados também considerando-se os tratamentos em que se utilizaram esterco de gado, embora em menor intensidade. Assim, à medida que foram utilizadas fontes de matéria orgânica pura, o desenvolvimento vegetativo foi menor, indicando a necessidade de misturas de palhadas e estercos. Trabalhos realizados por Costa et al. (2014) e Goulart (2008) mostraram que existe resposta do desenvolvimento vegetativo em função de níveis de matéria orgânica do solo, produzidas em maiores profundidades. Assim, à medida que aumentaram as misturas de palhadas, menores foram as populações de $P$. brachyurus, tanto em raízes de soja, quanto em solo. Também deve-se priorizar o manejo da fertilidade em profundidade de solo e a escolha de uma variedade de soja que apresente algum nível de resistência. Assim, se utilizadas culturas de cobertura com diferentes relações $\mathrm{C} / \mathrm{N}$, dentro de um programa de aumento de matéria orgânica em profundidade e/ou antagonismo, permite-se uma ferramenta a mais no manejo, como discutido anteriormente.

A matéria orgânica no perfil do solo também contribui com este manejo, segundo Costa (2012), existindo, assim, uma constante liberação de nutrientes para o desenvolvimento radicular em profundidade. Há também a possibilidade da matéria orgânica alterar a fisiologia do hospedeiro (maior resistência). Permite também o desenvolvimento de microrganismos antagonistas. Estes benefícios, contudo, são dependentes da relação $\mathrm{C} / \mathrm{N}$ da cultura de cobertura, permitindo uma liberação gradual de nutrientes (TEIXEIRA et al. 2009). Interessante ressaltar, porém, que há relatos de efeitos muito mais positivos se adicionado esterco no sistema produtivo (ZANE et al. 2019). Para exemplificar estas informações conflitantes, quando se trabalham com nematoides, pode-se observar as informações 
de Costa et al. (2014). Foram avaliados os níveis populacionais de $P$. brachyurus na cultura da soja, em área anteriormente implantada com coberturas de solo. Observou-se uma tendência de equilíbrio das populações com o passar do tempo, até os 70 dias após a emergência da soja implantada no local. Ou seja, ocorreu aumento naqueles tratamentos onde antes houve antagonismo (coberturas eficientes), e por outro lado, houve diminuição onde havia facilidade de multiplicação de $P$. brachyurus. Isto sugere, naturalmente, o efeito dos fatores edafo-climáticos, com temperaturas altas e grande precipitação, comum para a dinâmica populacional de nematoides, e estas condições tendem a facilitar o aumento dos níveis populacionais, mesmo em se tratando de sistemas eficazes para a redução populacional, dificultando o manejo destes parasitas.

Resultados semelhantes foram discutidos por Goulart (2008), em relação aos aspectos que influenciam o desenvolvimento de $P$. brachyurus nas condições tropicais. Ressalta-se por isso, a necessidade de fortalecer a formação de palhada e matéria orgânica no perfil de solo, para que as raízes sejam produzidas em maiores profundidades. Deve-se priorizar o manejo da fertilidade em profundidade de solo e a escolha de uma variedade de soja que apresente algum nível de resistência (rusticidade, por exemplo). Assim, mesmo que o controle dos nematoides não seja alcançado, o uso de matéria orgânica pode fazer parte de um conjunto de medidas que visam à manutenção desses patógenos abaixo do limiar de dano econômico. Diante da necessidade de um conjunto de estratégias, quando se fala em manejo integrado de nematoides, a utilização do esterco bovino e coberturas de solo deve ser intensificada, pois apresenta grande efetividade na redução populacional e estímulo ao crescimento da soja.

\section{ESTRATÉGIAS DE UTILIZAÇÃO DA MATÉRIA ORGÂNICA E ESTERCO BOVINO NO CONTROLE DE NEMATOIDES NA CULTURA DA SOJA}

As áreas comprometidas com nematoides podem ser manejadas através da integração lavoura e pecuária, em um sistema de produção de grãos e animais. Este sistema permite exploração em esquemas de rotação ou de consórcio. Outro sistema que tem sido amplamente estudado é a integração lavoura-pecuária-floresta (MACEDO 2009). Nas propriedades em que se que adotam estes sistemas como estratégias de produção agrícola, além das melhorias nas propriedades do solo e redução da incidência de insetos-praga, doenças e plantas daninhas, pode-se beneficiar da melhor estabilidade de produção de forragem para alimentar o rebanho durante $o$ ano todo. As culturas de milho e de sorgo, com capacidade de competição com as gramíneas forrageiras Brachiaria (Trinius, 1826) Grisebach, 1853 e Panicum maximum Jacq., na fase inicial de estabelecimento, têm sido as mais adotadas. Nesta integração, a soja recebe um conjunto de benefícios fitossanitários e nutricionais. Os benefícios são ligados à sustentabilidade da produção, pois implicam numa série de melhorias das características dos solos, desde maior absorção de água, fornecimento de bases trocáveis e disponibilidade de substâncias nematicidas (BALBINO et al. 2012).

A integração entre a lavoura e a pecuária já era praticada há muitos anos, de forma plena ou eventual, em muitos países, com a utilização de resíduos de culturas na alimentação dos animais ou o pastejo das restevas de lavouras. Do ponto de vista das propriedades físicas e químicas do solo, há uma melhoria na fertilidade, pela ciclagem dos nutrientes e eficiência no uso de fertilizantes, em função das diferentes necessidades das culturas em rotação, essenciais para aumentar a resistência vegetal e conviver com certos níveis populacionais em solos agrícolas em que as plantas sofrem mais, com instabilidades edafo-climáticas (condições de solo e clima). As alterações nas propriedades físicas têm ocorrido com o aumento da estabilidade dos agregados, diminuição da densidade aparente, da compactação, e no aumento da taxa de infiltração de água. Com o avanço das pesquisas, este sistema mostrou que a produtividade das áreas aumenta, em função do aumento do armazenamento de nitrogênio, aumento da relação $\mathrm{C} / \mathrm{N}$ (carbono/nitrogênio) benéfica, e o maior fornecimento de elementos nutricionais à cultura da soja (PORTES et al. 2000; KLUTHCOUSKI \& ADAR 2003; KLUTHCOUSKI et al. 2003; JAKELAITIS et al. 2004; FREITAS et al. 2005; BALBINO et al. 2012).

Algumas espécies de gramíneas forrageiras podem aumentar a população do nematoide-das-lesões ( $P$. brachyurus). Nesse sentido, espécies mais suscetíveis e/ou hospedeiras devem ser substituídas por outras no esquema de rotação ou permanecerem menos tempo durante o ciclo de cultivo. Atualmente, no Brasil, as combinações que estão 
associadas aos mais graves problemas em plantio direto são as sucessões continuadas de soja/milho em áreas com o nematoide-das lesões e algodão/ milho ou algodão/milheto em áreas com o nematoide-das-galhas ( $M$. incognita). O manejo adequado desses nematoides é um grande desafio, tendo-se em vista que o método com mais chance de sucesso seria a própria mudança na sucessão, com a substituição do milho pela Crotalaria spectabilis ou C. ochroleuca, para o controle de P. brachyurus; e a substituição do milho ou do milheto por braquiárias (B. ruziziensis Germain, Evrard, 1953, B. decumbens Stapf. 1919, ou B. brizantha (Hochstetter, Richard, 1851) Stapf, 1919), P. maximum ou amendoim para o controle de M. incognita (INOMOTO et al. 2007; INOMOTO \& SILVA 2011).

Outra estratégia que tem sido intensificada nos últimos anos é o melhoramento genético das espécies utilizadas como coberturas, com menores fatores de reprodução dos nematoides. Com a evolução no conhecimento do funcionamento destes sistemas, compreendeu-se a importância das rotações de culturas e da necessidade de uso de múltiplas espécies, que produzam resíduos que cubram melhor o solo, deixem maior quantidade de palhada, distribuam seus sistemas radiculares pivotantes e/ ou fasciculados, mantenham ou aumentem os teores de carbono, e incrementem a densidade/riqueza macro e microbiológica (INOMOTO et al. 2007). Na Tabela 2, estão descritas as informações relativas à hospedabilidade de espécies de cobertura de solo para o nematoide-das-lesões.

As culturas de cobertura constituem alternativa promissora para o manejo de nematoides (FREITAS 2008). O autor observou que pode-se utilizar plantas armadilhas (há penetração, mas o nematoide não completa o seu desenvolvimento), maus hospedeiros (há penetração, mas poucos nematoides se desenvolvem) e aquelas que contêm compostos nematicidas e nematostáticos em seus tecidos, que podem ser liberados no meio externo. $O$ autor também relata a produção de substâncias tóxicas, provindas da decomposição, o desenvolvimento intenso de microrganismos e a possibilidade da matéria orgânica alterar a fisiologia do hospedeiro, o que resulta em maior resistência ao desenvolvimento do nematoide nas raízes. Durante o processo de decomposição da matéria orgânica no solo, ocorre com frequência a liberação de compostos tóxicos como ácidos acético, butírico e propiônico, além de amônia e nitritos.

As gramíneas tropicais, principalmente as braquiárias, desempenham um papel importante na cobertura do solo, na produção de palhada, no aumento do carbono, e na estruturação do solo para este manejo. $\mathrm{O}$ carbono incorporado ao solo por essas palhadas é melhor utilizado se o sistema de plantio adotado for o do plantio direto, e se no processo de rotação for utilizada uma leguminosa forrageira (de preferência antagonista a nematoides). Em vários casos o estoque de carbono tem superado os da vegetação natural tomada como referência

Tabela 2. Espécies utilizadas como cobertura e incorporação de matéria orgânica, com efeitos sobre os fitonematoides.

\begin{tabular}{|c|c|c|c|c|c|}
\hline Espécie* & $\begin{array}{l}\text { Heterodera } \\
\text { glycines } \\
\text { (nematoide- } \\
\text { dos-cistos) }\end{array}$ & $\begin{array}{l}\text { Meloidogyne } \\
\text { javanica } \\
\text { (nematoide- } \\
\text { das-galhas) }\end{array}$ & $\begin{array}{c}\text { Meloidogyne } \\
\text { incognita } \\
\text { (nematoide- } \\
\text { das-galhas) }\end{array}$ & $\begin{array}{l}\text { Rotylenchulus } \\
\text { reniformis } \\
\text { (nematoide- } \\
\text { reniforme) }\end{array}$ & $\begin{array}{l}\text { Pratylenchus } \\
\text { brachyurus } \\
\text { (nematoide- } \\
\text { das-lesões) }\end{array}$ \\
\hline Milheto & Não hospeda & Má hospedeira & Boa hospedeira & Não hospeda & Má hospedeira \\
\hline Braquiárias & Não hospeda & Não hospeda & Não hospeda & Não hospeda & Boa hospedeira \\
\hline Sorgo forrageiro & Não hospeda & Má hospedeira & Má hospedeira & Não hospeda & Boa hospedeira \\
\hline Pé-de-galinha & Não hospeda & Boa hospedeira & Boa hospedeira & Não hospeda & Boa hospedeira \\
\hline Nabo forrageiro & Não hospeda & Boa hospedeira & Boa hospedeira & Não hospeda & Má hospedeira \\
\hline Aveia preta & Não hospeda & Boa hospedeira & Boa hospedeira & Não hospeda & Má hospedeira \\
\hline Aveia branca & Não hospeda & Má hospedeira & Má hospedeira & Não hospeda & Boa hospedeira \\
\hline Girassol & Não hospeda & Boa hospedeira & Boa hospedeira & Não hospeda & Má hospedeira \\
\hline Milho & Não hospeda & Má hospedeira & Boa hospedeira & Não hospeda & Boa hospedeira \\
\hline
\end{tabular}

* Não hospedeira: reduz a população do nematoide. Boa hospedeira: aumenta a população do nematoide. Má hospedeira: apresenta respostas variáveis (varia de cultivar para cultivar). Adaptado de INOMOTO \& ASMUS (2009). 
(MACEDO 2009). Segundo Yagi et al. (2005), a escolha de culturas de cobertura é fundamental, com composição química de resíduos de alta qualidade nutricional nos sistemas de alta produção agrícola e de manejo de nematoides.

Vale ressaltar, porém, que a utilização de matéria orgânica e resíduos agrícolas de forma isolada pode não ser suficiente para o efetivo manejo de nematoides, necessitando utilizar um conjunto de estratégias como descrito em McSorley (2001). Este conjunto de estratégias está ligado ao planejamento e escolha de táticas de manejo integrado. Estudos de espécies de culturas de cobertura foram realizados por Inomoto et al. (2007), Machado et al. (2007) e Ribeiro et al. (2007), indicando aquelas que apresentem baixo fatores de reprodução do nematoide-das-lesões. Há indicações de espécies de crotalária, cultivares de milheto e outras culturas de cobertura que apresentam baixos fatores de reprodução deste parasita.

Dois ensaios foram conduzidos na região do Médio Norte de Mato Grosso, objetivando compreender a interação da matéria orgânica do solo com as culturas de cobertura no manejo do nematoide-das-lesões (COSTA et al. 2014). O Ensaio I foi estabelecido em uma área com $2,8 \%$ de matéria orgânica, enquanto o outro foi estabelecido em área com 3,5\% de matéria orgânica. Os autores avaliaram os seguintes tratamentos em cada uma das áreas: alqueive (testemunha capinada), pousio com dessecação, pousio sem dessecação, C. spectabilis Roth, B. decumbens, milho e milheto. A massa seca (ton/ ha) produzida no Ensaio I ( $1,8 \%$ de matéria orgânica) foi inferior àquela produzida no Ensaio II (3,5\% de matéria orgânica). Na comparação dos somatórios das coberturas, em média, o Ensaio II produziu 16\% a mais que o Ensaio I. Maiores valores de palhada foram produzidos, respectivamente, por $C$. spectabilis, $B$. decumbens, milho e milheto. Houve forte redução populacional de $P$. brachyurus, principalmente na área II, ressaltando a necessidade de níveis de matéria orgânica no perfil do solo, para obtenção de efeitos das coberturas de solo. Os dados obtidos corroboram as informações de Inomoto et al. (2006), Goulart (2008), Altmann (2010) e Costa (2012), que citam os benefícios de culturas de cobertura, como antagonistas e ideais para a recomendação em rotação ou consorciação, e gestão da matéria orgânica no perfil do solo, fundamental para o manejo inte- grado de nematoides.

Segundo Miotto et al. (2007), em estudos $\operatorname{com} C$. juncea L., a liberação do elemento nutricional nitrogênio é rápida (maior parte até os 45 dias após o corte), da mesma forma que o potássio, contidos na fitomassa desta cobertura. Assim, embora a crotalária seja uma cobertura de solo muito eficiente, atuando como planta armadilha (permite a entrada nas raízes, mas não permite alimentação de nematoides), liberando substâncias nematicidas na decomposição, e ainda contribuindo com a melhoria das propriedades físicas e químicas do solo, não deve ser recomendada em plantio solteiro, mesmo que se utilizem espécies de crotalárias produtoras de maiores biomassas.

No estado do Mato Grosso, tem sido observada dificuldade na obtenção de quantidades adequadas de resíduos vegetais, devido às condições edafo-climáticas (altas temperaturas, grandes precipitações e solos com altas porcentagens de areia). Assim, ocorre uma rápida decomposição do resíduo vegetal depositado sobre o solo, dificultando o manejo de nematoides e agravando as oscilações de fornecimento de nutrientes às culturas. Demanda, portanto, nestas condições, sistemas contínuos de rotação e consórcio. Como a taxa de decomposição dos resíduos vegetais nos cerrados (região tropical) pode ser até 10 vezes maior do que em regiões de clima temperado, é importante selecionar plantas de cobertura do solo que alcancem elevada produção de massa seca e com maior tempo de meia-vida, que é o tempo necessário para que metade da massa inicial de resíduos seja decomposta, o que proporciona elevada porcentagem de cobertura do solo e bom manejo de nematoides (FABIAN 2009; COSTA et al. 2014).

Não se recomenda, portanto, a área deixada em pousio (um ano sem plantio), em que a vegetação espontânea pode surgir de forma agressiva, a partir de bancos de sementes naturais, que são espécies mais adaptadas às condições adversas de clima e solo, proporcionando aumento de populações de nematoides (principalmente do nematoide-das-lesões) (FABIAN 2009; COSTA et al. 2014).

Segundo Fabian (2009), os resíduos vegetais para fins de ciclagem de nutrientes podem ser classificados em três tipos: 1 ) os de alta qualidade que apresentam baixa relação $\mathrm{C} / \mathrm{N}$ e baixos teores de lignina, como as leguminosas, que proporcionam 
um efeito mais direto na produtividade das culturas, pois se decompõem mais rapidamente, resultando em baixa porcentagem de cobertura do solo; 2 ) os de qualidade intermediária que são aqueles que promovem uma proteção do solo por um período mais longo; 3) os de baixa qualidade que apresentam alta relação $\mathrm{C} / \mathrm{N}$ e altos teores de lignina, como as gramíneas, que permanecem por mais tempo na superfície do solo. Contudo, quando o objetivo é proporcionar proteção ao solo pela manutenção da cobertura vegetal (resíduos), a classificação se inverte, considerando-se os de alta qualidade, aqueles com alta relação $\mathrm{C} / \mathrm{N}$ e altos teores de lignina. Isto reforça a importância do consórcio de cultivos, com diferentes relações $\mathrm{C} / \mathrm{N}$, objetivando-se a liberação gradual de elementos nutricionais, longa duração da cobertura do solo e controle de nematoides.

Assim, o tempo de permanência da cobertura de solo, até a decomposição (principalmente nos consórcios), após a semeadura da cultura principal, pode ser determinante para se alcançar maior efetividade deste manejo de nematoides sugerido. Sodré Filho et al. (2004) avaliaram milheto e crotalária, semeados em abril, e manejados após 67 e 95 dias respectivamente, quando apresentavam $50 \%$ de florescimento (manejo com roçadora). Aos 30 dias após o manejo, os resíduos de milheto e de crotalária eram de 83 e $87 \%$, respectivamente, e aos 90 dias após o manejo, a porcentagem caiu para $31 \mathrm{e}$ $50 \%$. Sabendo-se que a maior parte era de carbono, percebe-se a importância da maior formação de biomassa (palhada) inicial e principalmente o uso do consórcio de culturas para o manejo de nematoides. Cazzeta et al. (2005) em estudo semelhante, sob condições climáticas e de solo diferentes, observaram que 60 dias após a semeadura do milho, os resíduos vegetais de milheto e crotalária mantinham o solo com cobertura de 83 e $92 \%$, respectivamente. Este tempo de 2 a 3 meses é considerado adequado para a cultura da soja, contudo é importante lembrar que nosso objetivo é manter o solo coberto durante todo o ano para aumentar a taxa de biomassa vegetal e de matéria orgânica.

Soares (2006) manejou com roçadora as culturas de braquiária, milheto e crotalária em pleno florescimento. $\mathrm{O}$ autor verificou que logo após o corte, os resíduos cobriam $100 \%, 75 \%$ e $85 \%$ do solo, respectivamente. Após 21 dias, a cobertura proporcionada pela crotalária já havia sido reduzida para
$30 \%$, enquanto a braquiária e o milheto mantinham o solo com 99 e $62 \%$ de cobertura, respectivamente. Após 84 dias do corte, a braquiária ainda cobria $97 \%$ do solo, o milheto $50 \%$ e a crotalária apenas $15 \%$. O autor atribuiu a rápida decomposição da crotalária aos menores valores da relação $\mathrm{C} / \mathrm{N}$ e do teor de lignina, quando comparados aos valores da braquiária e do milheto, e sugeriu que este é um dos motivos da braquiária ganhar importância como cobertura para o manejo de nematoides na atualidade.

Como a maior parte dos nutrientes das plantas encontra-se nos resíduos vegetais, exercendo função estrutural ou como substância de reserva, parte do estoque de nutrientes (no consórcio) torna-se disponível para as plantas, contribuindo para o incremento do rendimento das culturas subsequentes (SOUZA \& MELO 2000). A ciclagem biológica dos nutrientes por meio dos resíduos vegetais é um mecanismo que resulta na conservação de nutrientes no sistema agrícola, permitindo o manejo de nematoides e a produção de grande quantidade de biomassa, mesmo em ambientes com solos relativamente pobres. Com o sistema de semeadura direta, provoca-se um mínimo de movimentação do solo, tendendo à conservação destes nutrientes. Este é o sistema que mais se aproxima de um ecossistema natural, fortalecendo o manejo integrado de nematoides (BOER et al. 2007).

Alguns estudos têm mostrado que a época do ano para o manejo das coberturas vegetais interfere diretamente na velocidade de decomposição dos resíduos vegetais e manejo de nematoides (TORRES et al. 2005; ESPÍNDOLA et al. 2006). Suzuki \& Alves (2006) destacaram que a semeadura de culturas de cobertura no início da primavera, antes da cultura principal, no início do período das chuvas, além de aumentar a produção de massa seca fornece nutrientes para as culturas de verão, com nematoides. Assim, na avaliação de nutrientes reciclados no sistema produtivo, Torres et al. (2005) observaram diferenças na quantidade obtida de coberturas semeadas na época chuvosa e na época seca, em um latossolo vermelho distrófico típico, textura franco-argilo-arenosa (Tabela 3). Observou-se que no somatório final de nitrogênio, fósforo e potássio (NPK), o milheto forneceu maior proporção que a braquiária e a crotalária (221-28-275, contra 173-16-151 e 194-15-261, respectivamente). Assim, as 3 espécies de cobertura disponibilizaram grande 
Tabela 3. Cultura de cobertura, época de implantação e quantidade nitrogênio (N), fósforo (P) e potássio (K) reciclados no sistema de produção, visando à disponibilização para as plantas e redução de efeitos dos nematoides.

\begin{tabular}{|c|c|c|c|c|}
\hline \multirow{2}{*}{ Cultura de cobertura } & \multirow{2}{*}{ Época de implantação } & \multicolumn{3}{|c|}{ Nutriente $(\mathrm{kg} / \mathrm{ha})$} \\
\hline & & N & $P$ & K \\
\hline \multirow{3}{*}{ Milheto } & Início das chuvas (agosto-setembro) & 165 & 023 & 219 \\
\hline & Estação seca (abril) & 056 & 005 & 056 \\
\hline & Soma $(N-P-K)$ & 221 & 028 & 275 \\
\hline \multirow{3}{*}{ Braquiária } & Início das chuvas (agosto-setembro) & 131 & 013 & 105 \\
\hline & Estação seca (abril) & 042 & 003 & 046 \\
\hline & Soma $(N-P-K)$ & 173 & 016 & 151 \\
\hline \multirow{3}{*}{ Crotalária } & Início das chuvas (agosto-setembro) & 118 & 011 & 215 \\
\hline & Estação seca (abril) & 076 & 004 & 046 \\
\hline & Soma $(N-P-K)$ & 194 & 015 & 261 \\
\hline
\end{tabular}

Fonte: TORRES et al. (2005).

quantidade de nutrientes, aliando mais benefícios aos já conhecidos efeitos sobre nematoides. Observou-se efeito significativo da utilização das coberturas, com o aumento dos teores de matéria orgânica nas camadas subsuperficiais, estabilidade dos agregados, porosidade e atributos químicos do solo.

Assim, as informações relatadas nesta revisão demonstram que se utilizadas culturas de cobertura com diferentes relações $\mathrm{C} / \mathrm{N}$, bem como esterco bovino, dentro de um programa de aumento de matéria orgânica em profundidade, permite-se uma ferramenta a mais no manejo de áreas comprometidas com fitonematoides. Os benefícios estão ligados ao rápido desenvolvimento da parte aérea, impulsionado pela proteção de raízes contra o ataque de nematoides, bem como pela nutrição eficiente, garantindo volume radicular, resistência interna e fluxo contínuo de água e nutrientes, como resumido na Tabela 4.

\section{CONSIDERAÇÕES FINAIS E PERSPECTIVAS}

As doenças causadas por nematoides em soja demandam práticas de manejo integrado da produção. Os estudos indicam a necessidade de ações que reduzam os níveis populacionais destes parasitas e processos contínuos de estímulo ao desenvolvimento radicular. $\mathrm{O}$ uso de matéria orgânica e esterco bovino apresenta-se como uma estratégia de manejo, devido a um conjunto de ações nematostáticas e nematicidas (liberação de compostos tóxicos tais como ácidos acético, butírico, propiônico e graxos voláteis, amônia e nitritos), efeito fisiológico (ácidos húmicos e fúlvicos que desencadeiam mecanismos de resistência vegetal, como a produção de fenóis e proteínas relacionadas à patogênese) e nutricional (ativação de enzimas catalisadoras para a maior absorção nutricional e hídrica) da cultura da soja. Essas práticas possibilitam um intenso desenvolvimento de populações de inimigos naturais, tornando o solo supressivo às populações de nematoides.

Com a evolução no conhecimento do funcionamento desses mecanismos, compreendeu-se a importância da adoção de medidas agronômicas de rotação e consórcio de culturas e de variedades, além de práticas mais ecológicas como a integração lavoura e pecuária e lavoura-pecuária-floresta. Assim, utilizam-se múltiplas espécies, para que produzam resíduos que cubram melhor o solo, deixem mais palhada, distribuam seus sistemas radiculares pivotantes e/ou fasciculados, mantenham ou aumentem os teores de carbono, e incrementem a densidade/riqueza macro e microbiológica.

Recomenda-se, portanto, aumentar a fertilidade do solo, por meio da rotação de culturas, da gestão da matéria orgânica com consorciação de culturas (antagonistas aos nematoides e de diferentes relações $C / N$ ), e uso do esterco bovino como fornecedor de substâncias indutoras de resistência, redutoras de nematoides e com melhores aspectos nutricionais. As estratégias também incluem a integração lavoura e pecuária ou lavoura-pecuária-floresta. 
Tabela 4. Efeitos diretos e indiretos da utilização de coberturas de solo, palhada e matéria orgânica sobre o desenvolvimento populacional dos nematoides e na fisiologia vegetal do hospedeiro infectado.

Ações da matéria orgânica no solo (palhadas, raízes, tortas, estercos e derivados de animais e microrganismos em geral) e das espécies de cobertura utilizadas.

1) Modifica as condições físico-químicas do solo que podem alterar a relação hospedeiro-parasita (substâncias e elementos nutricionais).

- Disponibiliza gradualmente os nutrientes às plantas.

- Atua como agente de estabilização dos agregados do solo.

- A matéria orgânica no perfil do solo (em profundidade), dependendo da cobertura utilizada, recicla nutrientes das camadas profundas e eleva a taxa de utilização de nutrientes, tais como fósforo, potássio e nitrogênio.

- Minimiza as perdas por lixiviação e reserva água para pelo menos 20 dias.

2) Torna o solo supressivo aos nematoides.

- Favorece/incentiva o equilíbrio microbiológico no solo e o desenvolvimento de microrganismos antagonistas (multiplicação de bactérias, fungos, actinomicetes, nematoides predadores e protozoários).

- Fonte de energia para a atividade microbiana antagonista.

3) Efeito direto nematicida, nematostático e sobre a eclosão de nematoides.

- Libera amônia, ácidos acético, butírico, propiônico e graxos voláteis, além de nitritos e compostos tóxicos com efeito nematicida, nematostático ou ainda que podem interferir na eclosão de juvenis.

- Efeito armadilha das espécies de coberturas utilizadas (há penetração, mas o nematoide não completa o seu desenvolvimento), maus hospedeiros (há penetração, mas poucos nematoides se desenvolvem) e aquelas que contêm compostos nematicidas e nematostáticos em seus tecidos, que podem ser liberados no meio externo.

4) Efeito sobre a fisiologia vegetal e a resistência/tolerância aos nematoides.

- Permite, com a decomposição, a produção de substâncias húmicas (ácidos húmicos e fúlvicos) que agem no metabolismo vegretal, com estímulo direto no desenvolvimento (crescimento inicial das raízes e auxílio na defesa da planta contra nematoides).

- Acelera o desenvolvimento radicular das culturas, o que permite maior utilização de nutrientes, diminuindo os efeitos dos danos causados pelos nematoides.

- Com a liberação de substâncias húmicas, estimula a expressão de proteínas e a síntese de determinados constituintes proteicos como lectinas, inibidores de proteases serínicas e cisteínicas, polifenoloxidases, peroxidases, fenilalaninaamônia-liase e as proteínas relacionadas à patogênese essenciais na proteção contra os nematoides.

- Eleva o nível de fenóis nas raízes da planta hospedeira, deforma as células gigantes, reduz o tamanho das fêmeas, engrossa as paredes celulares, reduz a quantidade de núcleos das células gigantes e proporciona a deposição de caloses, o que torna as plantas mais resistentes.

\section{REFERÊNCIAS BIBLIOGRÁFICAS}

AGUIRRE E, LEMÉNAGER D, BACAICOA E, FUENTES M, BAIGORRI R, ZAMARREÑO, AM, GARCÍA-MINA JM (2009). The root application of a purified leonardite humic acid modifies the transcriptional regulation of the main physiological root responses to Fe deficiency in Fe-sufficient cucumber plants. Plant Physiology and Biochemistry 47: 215-223. (https://doi.org/10.1016/j. plaphy.2008.11.013).

ALMEIDA EJ (2008). Meloidogyne mayaguanensis - O nematoide da goiabeira. Available at: http:// todafruta.com.br/todafruta. Accessed on November 20, 2020.

ALTMANN N (2010). Plantio direto no Cerrado: 25 anos acreditando no sistema. Passo Fundo: Aldeia Norte Editora.
ALVES FR, FREITAS LG, MARTINELLI PRP, MEIRA RMSA, FERRAZ S, DEMUNER AJ, BORGES EEL, JESUS JÚNIOR WC (2007). Efeitos de diferentes níveis de matéria orgânica no solo e de inóculo sobre a interação planta - Meloidogyne spp. e a produção massal de Pasteuria penetrans. Summa Phytopathologica 33 (4): 397-401. (https://doi. org/10.1590/S0100-54052007000400013).

ASMUS GL (2001). Danos causados à cultura da soja por nematoide do gênero Meloidogyne In. Ferraz LCCB, Asmus GL, Carneiro RG, Mazaffera P, Silva JFV (Eds.) Relações parasito-hospedeiro nas meloidogynoses da soja. Londrina: Embrapa. pp. 39-62.

BALBINO LC, VILELA L, CORDEIRO LAM, OLIVEIRA P, PULROLNIK K, KLUTHCOUSKI J, SILVA JLS (2012). Módulo: Integração Lavoura-pecuária-floresta (ILPF) Região Sul. Curso de capacitação do programa ABC (Agricultura de baixo carbono). 
BOER CA, ASSIS RL, SILVA GP, BRAZ AJBP, BARROSO ALL, CARGNELUTTI FILHO A, PIRES FR (2007). Ciclagem de nutrientes por plantas de cobertura na entressafra em um solo de cerrado. Pesquisa Agropecuária Brasileira 42 (9): 1269-1276. (https://doi.org/10.1590/S0100204X2007000900008).

BOWDEN CL, EVANYLO GK, ZHANG X, ERVIN, EH, SEILER JR (2010). Soil carbon and physiological responses of corn and soybean to organic amendments. Compost Science and Utilization 18: 162-173. (https://doi.org/10.1080/106565 7X.2010.10736952).

BRAIDA JA, REICHERT JM, REINERT DJ, VEIGA M (2010). Teor de carbono orgânico e a susceptibilidade à compactação de um Nitossolo e Argissolo. Revista Brasileira de Engenharia Agrícola e Ambiental 14: 131-139. (https://doi.org/10.1590/ S1415-43662010000200003).

CANELLAS LP, SANTOS GA, RUMJANEK VM, MORAES AA, GURIDI F (2001). Distribuição da matéria orgânica e características de ácidos húmicos em solos com adição de resíduos de origem urbana. Pesquisa Agropecuária Brasileira 36 (12): 1529-1538. (https://doi.org/10.1590/S0100204X2001001200010).

CAZZETA DA, FORNASIERI FILHO D, GIROTTO F (2005). Composição, produção de matéria seca e cobertura do solo em cultivo exclusivo e consorciado de milheto e crotalária. Acta Scientiarum: Agronomy 27 (4): 575-580. (doi: 10.4025/actasciagron.v27i4.1298).

CHEN MS (2008). Inducible direct plant defence against insect herbivores: A review. Insect Science 15: 101-114. (https://doi.org/10.1111/j. 1744-7917.2008.00190.x).

COSTA MJN (2012). Nematoides: consorciação e rotação de culturas. In: Paterniani MEAG, Duarte AP, Tsunechiro A. Diversidade e inovações na cadeia produtiva de milho e sorgo na era dos transgênicos. Campinas: Instituto Agronômico, Associação Brasileira de Milho e Sorgo. pp. 367-378.

COSTA MJN, PASQUALLI RM, PREVEDELLO R (2014). Efeito do teor de matéria orgânica do solo, cultura de cobertura e sistema de plantio no controle de Pratylenchus brachyurus em soja. Summa Phytopathologica 40 (1): 63-70. (https://doi. org/10.1590/S0100-54052014000100009).

Coutinho RR, Faleiro VO, Neto ALF, Meneguci JLP, Freitas LG. (2018). Comunidades de nematodos como indicadores biológicos de perturbações em sistemas agrícolas. Nematropica 48: 186-197. (http://www.alice.cnptia.embrapa.br/alice/handle/doc/1103869).

DE WIT PJ (2007). How plants recognize pathogens and defend themselves. Cell Molecular Life Science 64: 2726-2732. (doi: 10.1007/s00018-0077284-7).

DIXIT G. (2005) Studies on multiple cropping systems for sustainable management of nematodes. In: Bandopadhyay (Ed.) Sustainable Agriculture. Northern Book Centre, New Delhi. pp. 116- 121.

DUFRANC G, DECHEN SCF, FREITAS SS, CAMARGO AO (2004). Atributos físicos, químicos e biológicos relacionados com a estabilidade de agregados em dois latossolos em plantio direto no Estado de São Paulo. Revista Brasileira de Ciência do Solo 28: 505-517. (https://doi.org/10.1590/S010006832004000300012).

EMBRAPA (2017). Eficiência de fungicidas para o controle da ferrugem-asiática da soja, Phakopsora pachyrhizi, na safra 2016/17: resultados sumarizados dos ensaios cooperativos. Londrina: Embrapa Soja.

ESPINDOLA JAA, GUERRA JGM, ALMEIDA L, TEIXEIRA MG, URQUIAGA S (2006). Composição e liberação de nutrientes acumulados em leguminosas herbáceas perenes consorciadas com bananeira. Revista Brasileira de Ciência do Solo 30: 321-328. (https://doi.org/10.1590/S010006832006000200012).

FABIAN AJ (2009). Plantas de cobertura: efeito nos atributos do solo e na produtividade de milho e soja em rotação. Universidade Estadual Paulista Júlio de Mesquita Filho. Tese (Doutorado em Agronomia), Jaboticabal, São Paulo, SP, Brasil.

FERRAZ LCCB (2001). As meloidoginoses da soja: passado, presente e futuro. In. Silva JFV, Mazaffera P, Carneiro RG, Asmus GL, Ferraz LCCB (Eds.) Relações parasito-hospedeiro nas meloidoginoses da soja. Londrina, Embrapa Soja: Sociedade de Nematologia.

FONSECA HS, FERRAZ LCCB, MACHADO SR (2003). Comparative ultrastructure of rubber tree roots parasitized by Meloidogyne exigua and Meloidogyne javanica. Nematologia Brasileira 27 (2): 199-206.

FREITAS FCL, FERREIRA LR, FERREIRA FA, SANTOS MV, AGNES EL, CARDOSO AA, JAKELAITIS A (2005). Formação de pastagem via consórcio 
de Brachiaria brizantha com o milho para silagem no sistema de plantio direto. Planta Daninha 23 (1): 49-58. (https://doi.org/10.1590/S010083582005000100007).

FREITAS LG (2008). Controle alternativo de fitonematoides. Tropical Plant Pathology 33: 34-36.

FURLANETTO C, DAVI JJS, GRABOWSKI MMS, DIAS-ARIEIRA CR, LAYTER NA, SEIFERT K (2008). Reação de adubos verdes de verão ao nematoide Tubixaba tuxaua. Tropical Plant Pathology 33: 403-408. (https://doi.org/10.1590/S1982$56762008000600001)$.

FURLANETTO C, SEIFERT KE, FENSTERSEIFER CE, PAGE EC, DAVI JJS, GRABOWSKI MMS (2010). Desenvolvimento das culturas de soja, milho e trigo cultivadas em áreas infestadas com o nematoide Tubixaba tuxaua no Oeste do Paraná. Tropical Plant Pathology 35 (5): 295-302. https://doi. org/10.1590/S1982-56762010000500004.

GALBIERI R, BELOT JL (2016). Nematoides fitoparasitas do algodoeiro nos cerrados brasileiros: Biologia e medidas de controle. Cuiabá-MT.

GOULART AMC (2008). Aspectos gerais sobre nematoides-das-lesões (Gênero Pratylenchus). Planaltina: Embrapa Cerrados, Documentos 219.

GUILFOYLE TJ, HAGEN G (2007). Auxin response factors. Current opinion in plant biology, 10: 453460. (doi: 10.1016/j.pbi.2007.08.014).

HIRAKURI MH (2014). Impactos econômicos de estresses bióticos e abióticos na produção de soja. Embrapa Soja, Circular Técnica, 105.

INOMOTO MM, ASMUS GL (2009). Culturas de cobertura e de rotação devem ser plantas não hospedeiras de nematoides. Visão Agrícola, 6 (2): 112-116.

INOMOTO MM, MOTTA LCC, MACHADO ACZ, SAZAKI CSS (2006). Reação de dez coberturas vegetais a Pratylenchus brachyurus. Nematologia Brasileira, 30 (2): 151-157.

INOMOTO MM, MACHADO ACZ, ANTEDOMÊNICO SR (2007). Reação de Brachiaria spp. e Panicum maximum a Pratylenchus brachyurus. Fitopatologia Brasileira, 32 (4): 341-344. (https://doi. org/10.1590/S0100-41582007000400009).

INOMOTO MM (2008). Importância e manejo de Pratylenchus brachyurus. Revista Plantio Direto, Passo Fundo, 108, 18: 4-9.

INOMOTO MM, SILVA RA (2011). Importância dos nematoides da soja e influência da sucessão de cultura. In: Siqueri F, Caju J, Moreira M (Eds.) Bole- tim de Pesquisa de Soja 2011. Fundação MT: Rondonópolis, pp. 392-399.

JAKELAITIS A, SILVA AA, FERREIRA LR, SILVA AF, FREITAS FCL (2004). Manejo de plantas daninhas no consórcio de milho com capim-braquiária (Brachiaria decumbens). Planta Daninha, Viçosa, 22 (4): 553-560. (https://doi.org/10.1590/S010083582004000400009).

KIMPINSKI JCE, GALLANT R, HENRY JA, MACLEOD

JB, SANDERSON SAV (2003). Effect of compost and manure soil amendments on nematodes and on yields of potato and barley. Journal of Nematology, 35 (3): 289-293.

KLUTHCOUSKI J, AIDAR H (2003). Implantação, condução e resultados obtidos com o Sistema Santa Fé. In: Kluthcouski J, Stone LF, Aidar H. (Eds) Integração Lavoura-Pecuária. Santo Antônio de Goiás: Embrapa Arroz e Feijão.

KLUTHCOUSKI J, COBBUCI T, AIDAR H, COSTA JLS, PORTELA C (2003). Cultivo do feijoeiro em palhada de braquiária. Santo Antônio de Goiás: Embrapa Arroz e Feijão. Embrapa Arroz e Feijão. Documentos, 157. (http://www.infoteca.cnptia. embrapa.br/infoteca/handle/doc/212489).

LEMOS ML, GUIMARÃES DD, MAIA GBS, AMARAL GF (2017). Agregação de valor na cadeia da soja. Agroindústria, BNDES Setorial, 46: 167-217.

MACCARTHY P (2001). The principles of humic substances. Soil Science, 166 (11): 738-751. (doi:10.1097/00010694-200111000-00003).

MACEDA A, SILVA JF, DIAS WP, SANTOS JM, SOARES PLM, MARCONDES MC, LIMA CG (2009). Ocorrência de Scutellonema brachyurus em soja no Brasil. In: International Congress of Tropical Nematology, Resumos... Maceió, AL, p. 105.

MACEDO MCM (2009). Integração lavoura e pecuária: o estado da arte e inovações tecnológicas. Revista Brasileira de Zootecnia, 38: 133-146. (https:// doi.org/10.1590/S1516-35982009001300015).

MACHADO ACZ, MOTTA LCC, SIQUEIRA KMS, FERRAZ LCC, INOMOTO MM (2007). Host status of green manures for two isolates of Pratylenchus brachyurus in Brazil. Nematology, 9, 6: 799-805. (https://doi.org/10.1163/15685410778233115).

MCSORLEY R (2001). Multiple cropping systems for nematode management: a review. Soil and Crop Science, Gainesville, 60 (3): 132-142.

MEYER MC, FAVORETO L, KLEPKER D, MARCELINO-GUIMARÃES FC (2017). Soybean green stem and foliar retention syndrome caused by Aphelen- 
choides besseyi. Tropical Plant Pathology, 42 (5): 403-409. (https://doi.org/10.1007/s40858-0170167-z).

MIOTTO A, PREDEBON R, WILDNER LP, DENARDIN RBN, GATIBONI LC, GIURIATTI A (2007). Comportamento da cobertura de solo durante a decomposição da fitomassa de Crotalaria juncea $\mathrm{L}$. em condições de campo. In: Congresso Brasileiro de Ciência do Solo, Resumos... Viçosa, MG. p. 107. MORA V, BACAICOA E, ZAMARREÑO AM, AGUIRRE E, GARNICA M, FUENTES M, GARCÍA-MINA JM (2010). Action of humic acid on promotion of cucumber shoot growth involves nitrate-related changes associated with the rootto-shoot distribution of cytokinins, polyamines and mineral nutrients. Journal of Plant Physiology, 167: 633-642. (doi: 10.1016/j.jplph.2009.11.018).

NARDI S, TOSONI M, PIZZEGHELLO D, PROVENZANO MR, CILENTI A, STURARO A, RELLA R, VIANELLO A (2005). Chemical characteristics and biological activity of organic substances extracted from soils by root exudates. Soil Science Society of American Journal, 69: 125-135. (https://doi. org/10.2136/sssaj2004.0401).

NAZARENO GC (2009). Utilização de matéria orgânica no controle de nematoide-das-galhas em alface sob cultivo protegido. Dissertação (Mestrado em Agronomia), Universidade de Brasília, Brasília, DF, Brasil.

PINTO MS, RIBEIRO MJ, OLIVEIRA AG (2011). O estudo de genes e proteínas de defesa em plantas. Revista Brasileira de Biociências. Porto Alegre, 9 (2): 241-248. (http://www.alice.cnptia.embrapa. br/alice/handle/doc/970033).

PORTES TA, CARVALHO SIC, OLIVEIRA IP, KLUTHCOUSKI J (2000). Análise do crescimento de uma cultivar de braquiária em cultivo solteiro e consorciado com cereais. Pesquisa Agropecuária Brasileira, 35 (7): 1349-1358. (http://dx.doi.org/10.1590/ S0100-204X2000000700009).

QUAGGIOTTI S, RUPERTI B, PIZZEGUELLO D, FRANCIOSO O, TUGNOLLI V, MARDI S (2004). Effect of low molecular size humic substances on nitrate uptake and expression of genes involved in nitrate transport in maize (Zea mays L.). Journal of Experimental Botany 55: 803-813. (doi: 10.1093/ jxb/erh085. Epub 2004 Mar 12).

RIBEIRO NR, DIAS WP, HOMECHIN M, SILVA JFV, FRANCISCO A (2007). Avaliação da reação de espécies vegetais ao nematoide-das-lesões. In: Re- união de Pesquisa de Soja da Região Central do Brasil, Resumos... Rio Verde. GO, p. 228.

RIBEIRO NR, DIAS WP, SANTOS JM (2010). Distribuição de fitonematoides em regiões produtoras de soja do estado de Mato Grosso. Boletim de Pesquisa de Soja 2010, Fundação Mato Grosso. pp. 289-296.

RITZINGER CHSP, ALVES EJ (2001). Nematoides. In: Alves, E.J. (Ed.). Cultivo de bananeira tipo Terra. Cruz das Almas: Embrapa Mandioca e Fruticultura. pp. 117-122.

RODRIGUES AK, FREITAS LG, AZEVEDO AA, FERRAZ S (2003). Desenvolvimento de Pasteuria penetrans em Meloidogyne spp. parasitando diferentes espécies vegetais. Fitopatologia Brasileira, Brasília 28 (3): 267-272. (http://dx.doi. org/10.1590/S0100-41582003000300007).

ROSA AH, ROCHA JCC, SAREGENTINI JUNIOR E (2001). Humic substances and extraction. In: Swift RS, Spark KM (Eds.) Understanding and managing organic matter in soils, sediments and waters. New York: Wiley \& Sons, pp. 41-46.

RYAN CA (2000). The systemin signaling pathway: differential activation of plant defensive genes. Biochimica Biophysica Acta 1477: 112-121. (doi: 10.1016/s0167-4838(99)00269-1).

SANTOS DF, COSTA MJN, PAVLAK L (2017). Avaliação de diferentes tipos de palhadas e estercos sobre o desenvolvimento populacional do nematoide-das-galhas (Meloidogyne javanica), das lesões (Pratylenchus brachyurus) e vida livre na variedade de soja TMG 4182. Caderno de Publicações UNIVAG. pp.109-120.

SEIXAS CDS, NEUMAIER N, BALBINOT JUNIOR AA, KRZYZANOWSKI FC, LEITE RMVCL TECNOLOGIAS DE PRODUÇÃO DE SOJA. (2020). Sistemas de Produção/Embrapa Soja, ISSN 2176-2902, Londrina: Embrapa Soja.

SIQUEIRA-JÚNIOR CL, FERNANDES KVS, MACHADO OLT, CUNHA M, GOMES VM, MOURA D, JACINTO T (2002). $87 \mathrm{kDa}$ tomato cystatin exhibits properties of a defense protein and forms protein crystals in prosystemin overexpressing transgenic plants. Plant Physiology and Biochemistry 40: 247-254. (https://doi.org/10.1016/S09819428(02)01364-5).

SILVA RA, RACK VM, VIGOLO F, SANTOS PS, CASTRO RD, KOBAYASTI L. (2014). Correlação entre densidade populacional de nematoides e produtividade de algodoeiro. Bioscience Journal, Uber- 
landia, 30: 1, 210-218. (http://www.seer.ufu.br)

SOARES TG (2006). Produção de palhada e reciclagem de nutrientes de leguminosas e gramíneas para implantação do sistema plantio direto no Nordeste Paraense. Dissertação (Mestrado em Agronomia Solos e Nutrição de Plantas), Universidade Federal Rural da Amazônia, Belém, PA, Brasil.

SODRÉ FILHO J, CARDOSO NA, CARVALHO RAM (2004). Fitomassa e cobertura do solo de culturas de sucessão ao milho na Região do Cerrado. Pesquisa Agropecuária Brasileira. Brasília 39 (4): 327-334. (http://dx.doi.org/10.1590/S0100204X2004000400005).

SOUZA RM, NOGUEIRA MS, LIMA LM, MELARATO

M, DOLINSKI CM (2006). Manejo do nematoide-das-galhas da goiabeira em São João da Barra (RJ) e relato de novos hospedeiros. Nematologia Brasileira, Brasília, 30 (2): 165-169. (https://www. researchgate.net/publication/328203115).

SOUZA WJO, MELO WJ (2000). Teores de nitrogênio no solo e nas frações da matéria orgânica sob diferentes sistemas de produção de milho. Revista Brasileira de Ciência do Solo 24: 885-896. (http://dx. doi.org/10.1590/S0100-06832000000400020).

STANGARLIN JR, KUHN OJ, TOLEDO MV, PORTZ RL, SCHWAN-ESTRADA KRF, PASCHOLATI SF (2011). A defesa vegetal contra fitopatógenos. Scientia Agraria Paranaenis 10 (1): 18-46.

SUZUKI LEAS, ALVES MC (2006). Fitomassa de plantas de cobertura em diferentes sucessões de culturas e sistemas de cultivo. Bragantia 5: 121-127. (http://dx.doi.org/10.1590/S000687052006000100016).

TEIXEIRA CM, CARVALHO GJ, ANDRADE MJB, SILVA CA, PEREIRA JM (2009). Decomposição e liberação de nutrientes das palhadas de milheto e milheto + crotalária no plantio direto do feijoeiro. Acta Scientiarum 31, 4: 647-653. (http://dx.doi. org/10.1590/S1807-86212009000400015).

TORRES GRC, PEDROSA EMR, MOURA RM (2006). Sobrevivência de Rotylenchulus reniformis em solo naturalmente infestado submetido a diferentes períodos de armazenamento. Fitopatologia Brasileira 31: 203-206. (http://dx.doi.org/10.1590/ S0100-41582006000200015).

TORRES JLR, PEREIRA MG, ANDRIOLII, POLIDORO JC, FABIAN AJ (2005). Decomposição e liberação de nitrogênio de resíduos culturais de plantas de cobertura em um solo de cerrado. Revista Brasileira de Ciência do Solo 29 (4): 609-618. (http://dx.
doi.org/10.1590/S0100-06832005000400013).

TORRES JLR, PEREIRA MG (2008). Dinâmica do potássio nos resíduos vegetais de plantas de cobertura no cerrado. Revista Brasileira de Ciência do Solo 32 (4): 1609-1618. (http://dx.doi.org/10.1590/ S0100-06832008000400025).

TREVISAN S, PIZZEGUELLO D, REPERTIB, FRANCIOSO O, SASSI A, PALME K, QUAGGIOTTI S, NARDI S (2010). Humic substances induce lateral root formation and expression of the early auxin-responsive IAA 19 gene and DR5 synthetic element in Arabidopsis. Plant Biology 12: 604-614. (https:// doi.org/10.1111/j.1438-8677.2009.00248.x).

USDA (2020). World Agricultural Supply and Demand Estimates. Available at: https://www.usda.gov/ oce/commodity/wasde/. Acessed on September 12, 2020.

VERLINDEND, PYCKE B, MERTENSJ, DEBERSAQUES F, VERHEYEN K, BAERT G, BRIES J, HAESAERT G (2009). Application of humic substances results in consistente increases in crop yield and nutrient uptake. Journal of Plant Nutrition 32: 1407-1426. (https://doi.org/10.1080/01904160903092630).

YAGI R, FERREIRA ME, CRUZ MCP, BARBOSA JC, ARAUJO LAN (2005). Soil organic matter as a function of nitrogen fertilization in crop successions. Scientia Agrícola 62 (4): 374-380. (http://dx.doi. org/10.1590/S0103-90162005000400011).

YUE P, SLEPER DA, RAO-ARELLI AP (2000). Genetic analysis of resistance to soybean cyst nematode in PI 438489B. Euphytica 116 (2): 181-186. (https://doi.org/10.1023/A:1004054731652).

ZANDONADI DB, CANELLAS LP, FAÇANHA AR (2007). Indolacetic and humic acids induce lateral root development through a concerted plasm plasmalemma and tonoplast $\mathrm{H}+$ pumps activation. Planta 225: 1583-1595. (doi:10.1007/ s00425-006-0454-2).

ZAMDONADI DB, SANTOS MP, DOBBSS LB, OLIVARES FL, CANELLAS LP, BINZEL ML, OKOROKOVA-FAÇANHA AL, FAÇANHA AR (2010). Nitric oxide mediates humic acids induced root development and plasma membrane H+ATPase activation. Planta 231 (5): 1025-1036. (doi: 10.1007/s00425010-1106-0).

ZANE J, GRABAU YB, JEFFREY AV, SENYU, C (2019). Swine manure application enriches the soil food web in corn and soybean production. Journal of Nematology 51: 1-14. (doi: 10.21307/jofnem-2019-014). 